\title{
Instructional Materials and Design: Issues and Challenges
}

\author{
Onyia, Mary N
}

\author{
Department of Curriculum Studies \\ Enugu State College of Education, \\ Enugu-Nigeria
}

\section{Doi:10.5901/ajis.2013.v2n6p153}

\begin{abstract}
This study was carried out in Udi Education Zone of Enugu State to investigate the design of instructional materials for teaching in secondary schools. The study adopted ex-post facto research design. The population comprised 1528 teachers from the education zone. Questionnaire was the instrument for data collection. Two research questions and one hypothesis guided the study. Mean and standard deviations were used to analyze the two research questions while t-test statistic was employed in testing the stated hypothesis. The findings indicated that instructional materials designed and used by the schools were of no quality, out-dated, cost effective and did not encourage intellectual development of the students. The findings also showed that the following criteria should form the basis for the designing of instructional materials for effective teaching and learning include materials that are durable, less costly, easily maintained and manipulated by students, appeal to students' interest and developed their intellectual capacities. The researcher recommended that government should make policies that should guide the design and production of instructional materials for use in schools.
\end{abstract}

\section{Introduction}

Instructional materials are the basic tools upon which the quality of education being provided to the children in schools is determined. They help in not only simplifying learning but in making learning practical, effective and understandable to the learners as well as help the students to maintain flexible classroom environment. Onyeachu (2010) defined instructional materials as ways and means of making the teaching and learning process easy, more meaningful and understandable. In a similar definition, Babalola (2004) explained that instructional materials are designed to promote and encourage effective teaching and learning experiences. Instructional materials are therefore, sight tools for teachers at all levels of education for effective instructional delivery and promotion of learner's academic achievement. Appreciating the importance of instructional materials Dike (1987) described them as alternative channels of communication which a teacher can use to compressed the information and make them more vivid to his learners

The roles of instructional materials in teaching learning process in schools cannot be emphasized. However, these essential instructional materials are often unavailable in most schools. The unavailability of these instructional materials in secondary schools often lead the teachers to talk and chalk as they have no visual or audio visual aids to see, touch, smell and hear in the process of teaching and learning. Hence, Onyeachu (2006) observed that when the instructional materials are not available, learners cannot do well. This implies that when learners are not doing well the set objective of education cannot be realized. This is why the emphasis in curriculum implementation calls for adequate instructional materials in schools.

The available ones appear to be poorly designed, old fashioned and no longer appropriate for modern teaching methods in schools. The apparent poor designed and inadequate instructional 
materials affect the teachers' teaching methods and hinder the academic achievement of the students. The situation calls for a new approach towards designing appropriate and modern suitable as well as less expensive but effective instructional materials to enhance quality teaching and learning in schools. Sumarni \& Guan (2007) defined instructional design as the systematic process of translating principles of learning and instruction into plans for instructional materials and activities. They further stressed that it can also be defined as a process, a discipline, a science or reality.

According to Thompson (2001) instructional design (also called Instructional System Design (ISD) is the practices of creating instructional experience which make the acquisition of knowledge and skill more efficient, effective, and appealing. The process consists broadly of determining the current state and needs of the learner, defining the end goal of instruction, and creating some intervention to assist in the transition. Ideally the process is informed by pedagogically (process of teaching) and andragogically (adult learning) tested theories of learning and may take place in student-only, teacher-led or community-based settings. The outcome of this instruction may be directly observable and scientifically measured or completely hidden and assumed.

As applied here, instructional design is creating opportunities which aid easy acquisition of knowledge and skills effectively by students in schools. It facilitates learning, and ensures active involvement of the students in the learning process. It becomes imperative that in designing of instructional materials, efforts have to be made to include the criteria for the three domains of educational objectives, so as to integrate the overall achievement of learning. This implies considering the age, ability, interest as well as its production cost and availability in the teaching environment.

Objectives of any level of education cannot be achieved if planned programme for such level of education is not well executed. In teaching process the teachers are the executors of curriculum implementation in schools. This they can only achieve when the necessary instructional materials are provided both in quality and quantity. Onyeachu (2008) asserted that no matter how well a curriculum plan is, if there are poor planned and designed instructional materials and other inputs the aims may not be achieved. Mkpa (2005) explained that instructional materials need to be made available and of high quality and can easily be improvised to meet the needs and aspirations of the learners in the teaching learning process. It is against this backdrop that the present study investigated the quality of the design of the available instructional materials for teaching and learning in schools in public secondary schools in Udi Education Zone of Enugu State.

\section{Statement of the Problem}

Teaching is a concept that demands that teachers should not only have the knowledge and skills but also the professional competence in the use of methods and materials to be able to influence the behaviour of learners using instructional materials. However, in secondary schools, instructional materials appear not to be only inadequate but also of poor designed quality. The result is that the students and teachers do not effectively utilize the learning opportunities provided by such materials in the teaching learning process.

This situation calls for appropriate design and use of quality instructional materials to enhance quality teaching and learning and achieved educational objectives of the learners in schools. The problem of this study therefore is: To what extent are the available instructional materials designed and used in secondary schools meet the needs of students in our school?

\section{Purpose of the Study}

The main purpose of this study was to investigate the design of suitable instructional materials for 
teaching and learning in Udi Education Zone of Enugu State. Specifically, the study determined;

1. The extent of the quality of the design of the available instructional materials in public secondary school in Udi Education Zone.

2. The criteria adopted for designing instructional materials for infective teaching and learning in secondary schools.

\section{Research Questions}

The following research questions guided the study:

1. To what extent is the quality of the design of the available instructional materials for teaching in secondary schools?

2. What steps can be adopted in designing suitable instructional materials for effective teaching in school?

\section{Hypothesis}

The following hypothesis was formulated to guide the study. There is no significant difference between the mean ratings of the students and teachers with regard to the design of instructional materials for teaching in schools.

\section{Methodology}

The study adopted ex-post facto research design in investigating the criteria for the designing of instructional materials for schools. The design was prefer because the researcher had no direct control of the variables as they already known in the study.

\section{Population of the Study}

The population of the study comprises all the 1528 teachers in the public secondary schools in Enugu North Education Zone of Enugu State.

\section{Sample and Sampling Technique}

Sample random technique was applied in selecting 10 out of the 25 public secondary schools in the zone. Stratified random sampling technique was employed in selecting 100 male and 140 female teachers from the 10 samples schools, giving the sample size 260 subjects.

\section{Instruments}

A researcher-developed questionnaire titled Instructional Materials Design Questionnaire (IMDO) was the instrument for data collection. It consisted of two sections. Section I gave demographic information about the respondents while section II contained 20 items built into clusters A and B. Cluster A provided information on the extent of the quality in the design of available instructional materials while cluster B provided data on the criteria to be adopted in designing suitable instructional materials for teaching and learning in schools. The instrument was face-validated by three experts, two from the Department of Science Education and one from Measurement and Evaluation, all of the Faculty of Education, University of Nigeria Nsukka. The items are based on four point ratings on real limit of numbers as follows; Very Great Extent (VGE), Great Extent (GE), 
Low Extent (LE) and Very Low Extent (VLE) with assigned values of $3.50-4.00,2.50-3.49,1.50$ -2.49 and $0.50-1.49$ respectively.

\section{Method of Data Collection and Data Analysis}

This researcher personally met with the respondents and administered and retrieved the questionnaire after completion. All the 260 copies of the questionnaires were duly returned, thus indicating $100 \%$ return rate. Mean and standard deviation were used in answering the research questions based on the real limit of numbers. A mean range of $2.50-3.49$ is the benchmark for acceptance while t-test statistic was employed in testing the stated hypothesis at 0.05 level of significance.

\section{Results}

The results of this study are presented in tables 1-3 below according to the research questions and the hypothesis that guided the study.

\subsection{Research Question One}

To what extent is the quality of the design of the available instructional materials in secondary school?

Table I: Mean scores of the respondents on the extent of quality of the design of instructional materials.

\begin{tabular}{clccc}
\multicolumn{2}{c}{$\mathrm{N}=260$} & & & \\
$\mathrm{~S} / \mathrm{N}$ & Extent of quality of the design of instructional materials & $\overline{\mathrm{X}}$ & $\mathrm{SD}$ & Remarks \\
1 & They are out-dated & 3.14 & 0.74 & $\mathrm{GE}$ \\
2 & The materials are not durable & 3.17 & 0.73 & $\mathrm{GE}$ \\
3 & Their maintenance cost is very high & 3.20 & 0.64 & $\mathrm{GE}$ \\
4 & They are of low quantity & 2.88 & 0.76 & $\mathrm{GE}$ \\
5 & They do match modern teaching methods & 3.34 & 0.68 & $\mathrm{GE}$ \\
6 & They are not easily improvised & 2.76 & 0.77 & $\mathrm{GE}$ \\
7 & Teachers rarely use them for instruction & 3.28 & 0.87 & $\mathrm{GE}$ \\
8 & They appeal only to the students' knowledge level & 2.93 & 0.80 & $\mathrm{GE}$ \\
9 & The materials do not appeal to students' interest & 2.92 & 0.79 & $\mathrm{GE}$ \\
10 & They are poorly designed & 2.89 & 0.81 & $\mathrm{GE}$
\end{tabular}

Data on table one above show that the ten items have mean score ranging from 2.76 to 3.34 . These show that in the opinion of the teachers, the instructional materials available in the school are to a high extent out-dated, not durable, have high maintenance cost, are of low quality and do not fit in the modern teaching method of teachers. They also agree that the materials are not easily improvised, they do not appeal to students' interest, not comprehensive in learning outcomes and of poor quality in design.

\subsection{Research Question Two}

What are the criteria to be adopted in designing suitable instructional materials for effective teaching in schools? 
Table 2: Mean ratings of the respondents on the criteria to be adopted in designing quality instructional materials in schools.

$$
N=260
$$

$\mathrm{S} / \mathrm{N} \quad$ Criteria for designing quality instructional materials

11 The design should encourage intellectual skills

12 Instructional materials should appeal to the students' interest

$\begin{array}{ccc}X & \mathrm{SD} & \text { Remarks } \\ 2.83 & 0.88 & \mathrm{GE} \\ 3.22 & 0.84 & \mathrm{GE} \\ 3.19 & 0.91 & \mathrm{GE} \\ 2.80 & 0.86 & \mathrm{GE} \\ 3.16 & 0.75 & \mathrm{GE} \\ 3.23 & 0.65 & \mathrm{GE} \\ 3.10 & 0.93 & \mathrm{GE} \\ 2.84 & 0.69 & \mathrm{GE} \\ 3.08 & 0.88 & \mathrm{GE} \\ 2.88 & 0.94 & \mathrm{GE}\end{array}$

13 They should be of high quality

14 The new designs should be affordable

15 They can easily be improvised

16 Their storage system should be simple

17 They should encourage concept learning

18 They should be easily manipulated by students

19 They should encourage high reasoning skills

20 They should be easily maintained in schools

Data on table 2 above indicate that all the items have their mean score ranging from 2.80 to 3.33 . These show that in the opinions of the teachers, the design of instructional materials should to a great extent be made to appeal to the intellectual skills, affective and psychomotor development of he students. Other needed qualities in the design include durability, easy to improvise, easy to manipulate by students' and those with low maintenance cost as well as have good storage mechanism.

Table 3: summary of t-test analysis for hypothesis one

$\begin{array}{cccccccccc}\text { S/N } & \text { Groups } & \mathrm{N} & \overline{\mathrm{X}} & \mathrm{SD} & \mathrm{df} & \begin{array}{c}\text { Sign } \\ \text { level }\end{array} & \begin{array}{c}\text { Cal-t } \\ \text { value }\end{array} & \begin{array}{c}\text { Tab-t } \\ \text { value }\end{array} & \text { Decision } \\ 1 & \text { Male } & 120 & 3.04 & 0.87 & 258 & 0.05 & 1.64 & 1.96 & \text { Accepted } \\ 2 & \text { Female } & 140 & 2.99 & 0.75 & & & & & \end{array}$

Result of the t-test analysis in table 3 indicated that the calculated t-value, 1.64 less than the tabulated t-value 1.96 at 258 degree of freedom and 0.05 level of significance. The null hypothesis is accepted. Therefore, there is no significant different between the mean ratings of male and female teachers with regard to criteria for designing instructional materials for teaching in schools in Udi Education Zone.

\section{Discussion}

It was the opinions of male and female teachers in public secondary schools in Udi Education zone of Enugu State that to a great extent, the instructional materials available for use in school are of inferior design, out-dated, not durable and have high maintenance cost. The respondents also shared the same opinion that they are of low quality, do not appeal to students intellectual development, do not match the new teaching methods of the teachers and were poorly designed. The findings agree with the news of Mkpa (2003) that in most schools, the available instructional materials are of poor quality in design. The findings are also supportive of Babalola (2004) that most of the available instructional materials in use in schools are lacking in stimulating the students intellectual growth.

The findings on this research question show that in the opinion of the teachers, in designing instructional materials, the following should be considered to a great extent. The listed qualities include instructional materials that should stimulate the intellectual capabilities of the students, those of durable quality and those that are easily improvised with low maintenance cost. The 
design should also ensure that students can easily manipulate the instructional materials as well being available in the schools. The above findings are in line with the views of Imogie (1990) and Fassai (2006) that modern designed instructional materials should be such that will be easily procured, maintained and cover the development of the three educational objectives. The result also is in agreement with the opinion of Ogbonnaya (1997) who recommended that instructional materials in schools should be designed in such a manner to stimulate problem-solving skills in the students.

The t-test analysis on table 3 showed that there was no significant difference between the opinions of male and female teachers in Udi Education Zone with regard to criteria for consideration in designing instructional materials for teaching in schools since the critical t-value of 1.96 is greater than the calculated t-value of 1.64 , at 2.58 degree of freedom and 0.05 level of significance, the null hypothesis is accepted.

\section{References}

Babalola, V.O. (2004). Resource materials in the implementation of curriculum in 21st century in Noah A.O.K. (ed) Curriculum implementation and professional teaching in Nigeria. Lagos: Central Education Services.

Dike, H.I. (1987). Production and utilization of educational technology materials in Nigerian research in education.

Mkpa, M.A. (2005). Challenges of implementing the school curriculum in Nigeria journal of curriculum studies $12(1), 9-17$.

Ogbonnaya, N.I. (1997) Teachers' perception of the management and maintenance of instructional materials in secondary schools. Health Movement Education J ournal I. (1), 135-143.

Omogie, I. (1990). Problems of integrating educational technology into teachers' education in Nigeria Review of Education 2, 26 - 34.

Onyeachu, J.A.E (2006). Integration of ICT(s) in teaching and distance learning in Nigeria. A paper presented at 16th annual national conference of Technological Writers Association of Nigeria (TEWAN) and faculty of education, Abia State University, Uturu, Wednesday, 5th -8th December 2007.

Onyeachu, J.A.E. (2008). Curriculum implementation at the primary education level challenges for the 21st century in multidisciplinary Journal of Research Development. 10 (1), 38 - 49.

Rio Sumarni \& J ulia guan Chin Hsien (2005). A constructivist-Contextual Multiple Intelligence Multimedia Courseware for Science Learning. Universiti Teknologi Malaysia: Technical Report (RMC vote 75290).

Siemens, G. (2002). Instructional Design in E-learning. http://www.elearnspace.org/Articales/ instructionalDesign.htm (Retrieved, July 9, 2007). 